\title{
Jehovas Vidner. I grænsefladen af den danske religionsmodel
}

\author{
ANNIKA HVITHAMAR
}

ENGLISH ABSTRACT: Jehovah's Witnesses have existed as a minority religion in Denmark for more than hundred years. I argue that even Jehovah's Witnesses are clearly within, although situated in the borderland of the Danish model of religion, they are also located in a borderland position when seen from juridical, theological and sociological points of views. I discuss the borderland position on the basis of a media debate that took place in the summer of 2013, when Jehovah's Witnesses were accused of racism due to speeches given at the yearly summer convent

DANSK RESUMÈ: Jehovas Vidner har eksisteret som minoritetsreligion i Danmark $i$ mere end hundrede år. Artiklen argumenterer for, at selv om Jehovas Vidner klart er indenfor, men i grænsefladen af den danske religionsmodel, er Jehovas Vidner stadig $i$ en grænseposition ud fra andre juridiske, teologiske og sociologiske synsvinkler. Denne grænseposition har dog flyttet sig længere og længere ind mod midten i de senere år. Artiklen diskuterer grænsepositionen ud fra en mediedebat $i$ sommeren 2013. Her blev Jehovas Vidner anklaget for racisme som følge af indhold $i$ taler afholdt på det årlige sommerstrone.

KEYWORDS: Jehovah's Witnesses; minority religion; inclusion; conflict

Ved Jehovas Vidners årlige sommerstævne i sommeren 2013 var temaet for en af talerne "Tag dig i agt for frafaldne!". ${ }^{1}$ Her omtalte taleren frafaldne Jehovas Vidner på denne måde:

Roskildesyge. Mon ikke det er noget, der giver associationer i dig, når du hører det ord. Måske har du gjort dig de smertelige erfaringer. Så er jeg ked af at minde dig om det. Hvis ikke du ved, hvad det er, så kan vi bare sige: "Du er ikke gået glip af noget!"

1 Taleren fremstår både i stævneprogrammet og i politianmeldelsen anonymt. Politianmeldelsen var følgelig rettet mod Jehovas Vidner i Danmark (Jehovas Vidners områdestævne. Program 2013). 
[...]Den åndelige sygdom, der hedder "frafalden", den kan på mange måder sammenlignes med en smittefarlig sygdom. Hvad er en frafalden? En frafalden er en, der har været i sandheden, men nu har forladt den og er blevet modstander af alt, der har med Jehova at gøre. Symptomerne på den sygdom er, at man udtaler sig imod sine tidligere trosfæller, og man har et brændende ønske om at trække andre ud af sandheden, ud af tilbedelsen for Jehova. Som du kan se, er det en dødsensfarlig sygdom. Hvilket åndeligt organ bliver angrebet, hvis du er angrebet af "frafaldensygen"? 1. Tim. 6:3 siger, at en der har forladt sandheden er syg i sindet eller fordærvet i sindet ("Tag dig i agt for frafaldne" 2013).

Talen er opbygget efter en retorisk model, som kendetegner Jehovas Vidners skrifter og foredrag. Den tager udgangspunkt i en konkret, nutidig situation, som i dette tilfælde omhandler de frafaldne medlemmer af Jehovas Vidner. Der bruges konkrete eksempler, som vækker genkendelse hos tilhøreren, her ved at sammenligne med roskildesyge. Derefter fortælles det, hvor i Bibelen der gives retningslinjer for at forholde sig til problemet, her i forhold til 1. Tim, hvis tema er, hvordan menigheder skal opbygges og drives. Herunder, hvordan frafaldne fra menigheden skal opfattes.

Den klare afstandstagen fra eks-medlemmer, der er fjendtligt indstillede over for Jehovas Vidner, har været karakteristisk for bevægelsen helt tilbage fra dens konsolideringstid i begyndelsen af det 20. århundrede (Beckford 1975, 15-16, 55; Watch Tower Bible and Tract Society 1993, 186-87). Støttegruppen for tidligere Jehovas Vidner valgte dog den 25. juli 2013, på baggrund af denne tale, at indgive en anmeldelse af Jehovas Vidner til politiet (Politianmeldelse 30.7.2013) i forhold til Straffelovens $\S$ 266b.2 I løbet af den næste uges tid nåede sagen rundt i de danske trykte medier, og avisernes lederskribenter, religionspolitiske aktører og danske politiske partier bidrog med deres synspunkter på sagen. Efterfølgende blev anklagen ændret til kun at gælde to talere fra sommerstævnet. Disse blev afhørt i december 2013, men i august 2014 blev sagen henlagt af rigsadvokaten (Erik Jørgensen, personlig korrespondance, 8.8.2014).

Det er denne sag og dennes udtryk for, hvordan Jehovas Vidner balancerer i grænseområdet af den danske religionsmodel, som er omdrejningspunktet for denne artikel. I det følgende vil jeg efter at have diskuteret den danske religionsmodel analysere, hvordan Jehovas Vidner, historisk og i dag, bevæger sig i dette grænseområde.

2 \$266b lyder: Den, der offentligt eller med forsæt til udbredelse i en videre kreds fremsætter udtalelse eller anden meddelelse, ved hvilken en gruppe af personer trues, forhånes eller nedværdiges på grund af sin race, hudfarve, nationale eller etniske oprindelse, tro eller seksuelle orientering, straffes med bøde eller fængsel indtil 2 år. Stk. 2. Ved straffens udmåling skal det betragtes som en særligt skærpende omstændighed, at forholdet har karakter af propagandavirksomhed (Straffeloven). 


\section{Den danske religionsmodel}

"Religionsmodellen er det institutionaliserede og historisk betingede aftryk, som religionssystemets udvikling og interaktion med staten og samfundet har efterladt os med" (Christoffersen et al. 2012, 14). Den danske religionsmodel er dermed kendetegnet ved en række træk af historisk, sociologisk, teologisk og mentalitetsmæssig art, som kendetegner Danmark. Særligt er den kendetegnet ved et tæt forhold mellem et bestemt religiøst samfund, folkekirken, og den danske stat. Dette forhold er igen baseret på en tæt historisk sammenknytning mellem den lutherske kirke og den danske stat. I modsætning til de andre nordiske lande har Danmark indtil for nylig ikke haft religiøse minoriteter med så stor indflydelse, at de har kunnet påvirke religionsmodellen. Folkekirkeligheden er, måske derfor, kendetegnet ved liberalisme og sekularisering (Iversen 2012, 28, 34).

Der kan også argumenteres for, at den danske religionsmodel er påvirket af Grundtvigs frihedsbegreb. For Grundtvig var tanke- og åndsfrihed tæt knyttet til kravet om religionsfrihed (Jørgensen 2012, 193-194). Grundtvigs religionsopfattelse var rettet mod individets frihed i forhold til staten. Grundtvigianismens sejrsgang i det danske kirkelige landskab har gennem de sidste 150 år betydet, at den frie religionsudøvelse, som ikke kontrolleres af et højkirkeligt miljø, kendetegner religionsudøvelse i Danmark (Iversen 2012, 28).

I kort form kan det siges, at den danske religionsmodel er kendetegnet ved høj grad af religiøs autonomi blandt de praktiserende og en udbredt opfattelse af, at enhver er fri til at bestemme, hvordan deres religion skal praktiseres. Det udtrykkes direkte i grundlovens centrale paragraffer om religionsfrihed (§67) og frihed til at danne et trossamfund (\$70). Det er desuden en religionsmodel, der er stærkt påvirket af den udgave af kristendom, som formidles af den danske folkekirke.

\section{Jehovas Vidner som 'matter out of place'}

Religionssociologen Eileen Barker har påpeget, at nye religiøse bevægelser opfattes af majoritetssamfundet som det, Mary Douglas kaldte for "matter out of place" (Barker 2001, 202). Med dette udtryk mener Barker en forurening, som opstår, når et fænomen ikke kan kategoriseres i kendte grupper. Douglas pointerede, at mennesket skaber orden ud af kaos ved at kategorisere fænomener, ordne dem i grupper og adskille dem fra hinanden. Men i denne kategorisering opstår fænomener som svært lader sig kategorisere. Det er Barkers pointe, at minoritetsreligioner ofte får denne position, idet de, i deres religiøst betingede normer og forestillinger balancerer på grænsen af, hvad majoriteten ser som acceptabelt (Barker 1994, 97-98; 2006, 202).

I det følgende vil jeg argumentere for, at Jehovas Vidner bevæger sig i grænsefladen af den danske religionsmodel. Jehovas Vidner er på mange måder en integreret del af det danske religiøse landskab, men på afgørende områder adskiller bevægel- 
sen sig fra de normer, som religiøse minoriteter forventes at leve op til i den danske religionsmodel. Disse normer er blandt andet udtrykt i grundlovens bestemmelser om religionsfrihedens begrænsning (\$70) og om regler for godkendelse af trossamfund, herunder retten til at melde sig ud. Herved bliver Jehovas Vidner i Douglask forstand out of place (Barker, 2006, 207). De er religiøse og de er danske, men ikke på den helt acceptable måde

\section{Jehovas Vidner i Danmark}

Jehovas Vidner har eksisteret i Danmark siden 1895, og siden 1904 er bladet Vagttårnet regelmæssigt udkommet på dansk (Hvithamar 2007, 224-225). ${ }^{3}$ Bevægelsen blev i dens etableringsfase opfattet som kontroversiel, fordi Jehovas Vidner afgrænsede sig stærkt over for alle andre religioner, i Danmark over for den danske folkekirke. Modviljen var gensidig. Når Jehovas Vidner i det 20. århundrede sporadisk blev beskrevet i faglitteraturen, var det negativt. Jehovas Vidner blev betegnet som afvigende - både i religiøs og i psykologisk forstand. Fremstillingen af Jehovas Vidner i præsten og kirkehistorikeren Michael Neiiendams meget brugte bog Frikirker og Sekter, kan tjene som eksempel. ${ }^{4}$ I bogen, som blev genudgivet fire gange i løbet af århundredet, optræder Jehovas Vidner første gang i udgaven fra 1948 med følgende beskrivelse:

I en Organisation som "Jehovas Vidner" findes adskillige uens Typer, hos hvem Graderne i Had til og Bitterhed mod Samfundet ligger højere og lavere. Der er Kynikere, udpræget polemisk betonede Propagandister, som føler Fryd ved at kredse om de forestaaende Massakrer i Slaget ved Harmagedon. Der er nøjsomme, moralsk udadelige Mennesker, som i deres aandelige Jævnhed faktisk ikke kender alle Enkeltheder i Læren; de har, hvad man kalder Barnetroen i Behold, er besveget i dette svigefulde Liv, men er til Gengæld blevet grebet af den glødende Forkyndelse om den forestaaende Verdenskatastrofe, som skal forvandle denne Jammerdal til et Paradis, og de vil være på Herrens Side, naar han nu snart kommer igen (Neiiendam 1948, 222).

En opfattelse af Jehovas Vidner som mennesker, hvis medlemskab af bevægelsen er determineret af enten intellektuel, social eller psykisk uformåenhed, er karakteristisk for ovenstående citat. Det er en fremstilling, som ikke er ualmindelig for beskrivelser af minoritetsreligioner, men i denne sammenhæng er det også en fremstilling, som søger at placere Jehovas Vidner uden for den danske religionsmodel. Jehovas Vidner beskrives i ovenstående citat ikke som en del af det danske samfund, kendetegnet

3 Det var først i 1931, at Jehovas Vidner fik deres nuværende navn. Indtil da kaldte de sig selv Bibelstudenterne. Det var bevægelsens anden leder, J. F. Rutherford (1869-1941), som gav Jehovas Vidner sit navn. Han stod for en centralisering af bevægelsen og en skærpelse af dens grundlæggende forestillinger og grænser udadtil (Chryssides 2008, 121).

4 Frikirker og Sekter udkom første gang i 1927 og blev senest genoptrykt i 1958. 
ved et frit forhold til religion, men som individer, som står udenfor, og er drevet af had til samfundet.

Gennem størstedelen af det 20. århundrede betragtedes Jehovas Vidner som stående udenfor med en fejlagtig, asocial religionsudøvelse. Men i den sidste tredjedel af århundredet skete der en gradvis accept. Det er denne udvikling, jeg vil beskrive nedenfor.

\section{Juridiske grænsedragninger}

Den gradvise ændring af majoritetssamfundets opfattelse af Jehovas Vidner giver sig bedst til udtryk i den juridiske anerkendelse af bevægelsen og dens særsynspunkter. Da reglerne for godkendelse af trossamfund blev ændret i 1969 søgte Jehovas Vidner om at blive et godkendt trossamfund og blev godkendt i 1970 og fik dermed den blåstempling, som er implicit i statens godkendelse (Warburg 1996, 21). Den kendsgerning, at Jehovas Vidner faktisk søgte om godkendelse er et betydeligt skridt fra trossamfundets side mod at anerkende spillereglerne i den danske religionsmodel. I løbet af det 20. århundrede har medlemmer af Jehovas Vidner siddet i fængsel som et resultat af deres afvisning af militær værnepligt. Men i 1998 blev det muligt at aftjene civil værnepligt, og siden da har Jehovas Vidners afstandstagen fra at bære våben ikke været problematisk for den danske stat (Militærnægterloven §1, 2006). Derudover betød en udvikling i patientlovgivningen, at det siden 1998 har været en rettighed for patienter, at der ikke må indledes behandlinger, som indebærer transfusion af blod eller blodprodukter, uden patientens informerede samtykke (Sundhedsloven §24, 2010). Denne ændring i patientlovgivningen betød, at Jehovas Vidner nu fik ret til at afvise behandlinger med blod. ${ }^{5}$ Da denne lovgivning specifikt retter sig mod netop Jehovas Vidners særlige forhold til blodtransfusioner må lovændringen siges at være det mest vægtige udtryk for, at det danske samfund har anerkendt Jehovas Vidners synspunkter som legitime.

Den danske stat har gradvist accepteret særtræk ved Jehovas Vidner. Det skal dog understreges, at lovgivningen er et resultat af en forhandling gennem årene. På den ene side har Jehovas Vidner tilnærmet sig samfundet. I forhold til militærnægtelse tillod Jehovas Vidner ikke sine medlemmer at udføre militærnægtertjeneste frem til 1996, selvom det foregik ved civile myndigheder. Men i 1996 ændrede Det Styrende Råd holdning og vedtog, at det kun var den militære tjeneste, som Jehovas Vidner skulle tage afstand fra (Vagttårnet 5, 1996, 19-20). På den anden side har det danske samfund udviklet sig i retning af at tillade borgerne mere frihed i forhold til værnepligten. Det giver sig til udtryk i militærnægterloven, hvilket bevidner en generel positiv indstilling overfor afvisning af værnepligt. Godkendelsen af Jehovas

5 Se Hvithamar (2007) for en længere behandling af danske Jehovas Vidners forhold til værnepligt og behandlinger med blod, herunder hvordan Jehovas Vidners oprettelse af Afdelingen for Hospitalsinformation i 1979 sidenhen har påvirket udviklingen af blodløs kirurgi. 
Vidner som trossamfund og vedtagelsen af de to love er vigtige markeringer af, at Jehovas Vidner har bevæget sig fra at befinde sig langt ude i den danske religionsmodels grænseflade til at komme længere og længere indenfor.

\section{Teologiske grænsedragninger}

Det er afvisningen af treenighedslæren, som mest markant adskiller Jehovas Vidner fra de store kirkesamfund. De anser treenighedslæren for at være et resultat af en senere udvikling og ikke i overensstemmelse med, hvad Bibelen fortæller om Jesus' lære. Jesus opfattes i stedet som den første skabning (Hvad er det Bibelen virkelig lærer 2005, 41). Jehovas Vidners opfattelse kommer f.eks. til udtryk i Ny Verdenoversættelsen af Bibelen. Dette er blandt andet tilfældet i Joh 1, 1, der i Ny Verdenoversættelsen lyder "I begyndelsen var Ordet, og Ordet var hos Gud, og Ordet var en gud". Mens der i Bibelselskabets oversættelse står "I begyndelsen var Ordet og Ordet var hos Gud og Ordet var Gud". I Ny Verden-oversættelsen er "Ordet" således en selvstændig guddom, mens "Ordet" i Bibelselskabets oversættelse er en del af Gud.

Siden J. F. Rutherford i 1917 blev valgt som leder af bevægelsen (se ovenfor), har Jehovas Vidner været kritisk over for andre religioner, der identificeres som "Babylon den Store" i Joh Åb 17, 1, 15 (Holden 2002, 20; Chryssides 2008, 12-13). I bevægelsens skrifter indgår derfor også regelmæssigt anklager mod især andre kirkesamfund i forhold til teologiske uenigheder f.eks. om helgeners status (Vågn op! 11, 2010, 20 21), ikondyrkelse (Vågn op 8, 2008, 20-21) og præsters involvering i politik (Vågn op! 5, 2004, 3-5).

Også i 1990'ernes religionssociologiske forskningsformidling er forfatterne forbeholdne over for den teologiske legitimitet ved Jehovas Vidners afvisning af treenighedslæren. I gymnasiebogen Minoritetsreligioner i Danmark - Religionssociologisk set skriver lektor i kristendomshistorie Jørgen Skafte Jensen:

\footnotetext{
Ifølge denne [treenighedslæren] er Jesus Kristus Gud, nemlig Gud Sønnen. Dette centrale kristne dogme afvises af Jehovas Vidner. Det står der nemlig ikke noget om i Bibelen, siger de. Det korrekte i dette synspunkt kan naturligvis diskuteres, men vidnerne har naturligvis ret $i$, at Oldkirkens treenighedslære ikke findes i Bibelen i samme form, og at Bibelen i øvrigt er åben for fortolkninger, også når det gælder spørgsmålet om Jesus som gud. Det er måske alligevel værd at bemærke, at det kun er de moderne, bibelkritiske og "anti-fundamentalistiske" bibelforskere, der mener, at der kan være tvivl om, at forestillingen om Jesus som gud rent faktisk kan læses ud af teksterne (Jensen 1991, 156-57).
}

Det er interessant, at Jehovas Vidner her sættes på linje med "moderne, bibelkritiske" og "antifundamentalistiske bibelforskere", idet bevægelsens læsning af Bibelen netop er fundamentalistisk; men pointen er her, at Jehovas Vidner gennem deres manglen- 
de accept af treenighedslæren placeres uden for de bevægelser, som anerkender et centralt kristent dogme. Sådan som den danske folkekirke gør det.

Ud over treenighedslæren har der også været teologisk fokus på Jehovas Vidners eskatologi. At Jesus Kristus skal komme og dømme levende og døde er også en del af den apostolske trosbekendelse i folkekirkens højmesser. Men alligevel er Jehovas Vidners nærforventning et træk, der i majoritetskristendom opfattes som afvigende.

\section{Sociologiske grænsedragninger}

Ifølge den danske minoritetsforsker Helen Krag bliver minoriteter til i ordensparadigmer (Krag 2007, 61). Det vil sige som det, der er afvigende eller unormalt eller det som har behov for at blive tolereret. For i lighed med Barkers observation om minoriteter som grænsetilfælde, så kan minoriteter defineres som dem, der ikke rigtig hører til, blandt andet fordi de opfører sig på en anden måde og har andre normer og værdier end majoriteten. De repræsenterer en anden form for orden, og det gælder også for Jehovas Vidner.

Jehovas Vidner lever og arbejder blandt majoritetsbefolkningen og er, i en dansk sammenhæng, en forholdsvis stor bevægelse. ${ }^{6}$ Men deres normer og værdier er på kant med de nationale danske. De fejrer ikke nationale højtider som jul, personlige festdage som fødselsdage eller årstidshøjtider som fastelavn. De bruger ikke Dannebrog, og selv om Jehovas Vidner godt kan have venner og bekendte blandt ikkemedlemmer, er man påpasselig med at undgå skadelige påvirkninger fra den omkringliggende verden. I bevægelsen bruges begrebet at kunne "holde menigheden ren" (Watch Tower Bible and Tract Society 1993, 187). ${ }^{7}$ Da seksualnormerne i bevægelsen er konservative, tillades heller ikke sex før og uden for ægteskab eller praktiseret homoseksualitet (Vågn op! 1, 2012, 28-29; 9, 2013, 4-5). Set fra majoritetssamfundets side, afviser Jehovas Vidner fællesskabets normer og værdier. Medlemmer af Jehovas Vidner takker nej til fødselsdagsinvitationer, børn må ikke klæde sig ud til fastelavn, de tillader ikke kærester at bo sammen før ægteskab, og de afviser i det hele taget at deltage i fællesskabsritualer, som de anser som ikke-kristne. Derudover er det Jehovas Vidners praksis at udelukke medlemmer, som overtræder bevægelsens normer samt deres afvisning af at modtage blod, der medfører de største kontroverser i forhold til majoritetens normer og værdier. For ved ovenstående praksis sætter medlemmer af bevægelsen de religiøse værdier over alle andre værdier, inklusiv familiesammenhold og overlevelse, hvilket i en dansk kontekst er normbrydende.

6 Ifølge Jehovas Vidners egne tal var der 14.484 forkyndere i Danmark i 2013 (Jehovas Vidners årbog 2014 82). Tallet angiver Jehovas Vidner, som er aktive, hvorfor tal, som inkluderer udøbte børn og andre, som ikke er aktive, vil være noget højere. Som enkeltstående bevægelse gør det Jehovas Vidner til den største minoritetskristne gruppe i Danmark, bortset fra den katolske kirke.

7 Begrebet bygger på formaningerne fra 1. Kor $51-13$, hvor omgang med 'utugtige mennesker' forbydes. 
I forhold til andre danske religiøse grupper er Jehovas Vidners normer og værdier dog ikke altid enestående. Hvad angår seksualmoral er Jehovas Vidner på linje med maksimalistiske retninger inden for dansk islam og kristendom f.eks. Indre Mission. Ligesom man blandt mange religiøse minoriteter kan finde en påpasselighed mod at indgå i samme form for ungdomskultur som den dominerende danske. Det er i forhold til de nationale ritualer og fællesskabsritualer som fastelavn og fødselsdage, at Jehovas Vidner har særstandpunkter. Med andre ord er det de ofte overlappende ritualer, der dels knytter sig til det danske nationale fællesskab, dels til det folkekirkelige fællesskab, som gør Jehovas Vidner til en omstridt gruppe blandt andre religiøse mindretalsgrupper i den danske religionsmodels grænseflade. Desuden indebærer Jehovas Vidners overbevisning om at sætte de religiøse værdier over alle andre værdier, at de sætter sig udover det frihedsbegreb, som karakteriserer religionsudøvelsen i Danmark og som er et implicit normativt element i den danske religionsmodel.

\section{Sommerstævnet 2013}

Jehovas Vidners sommerstævne i 2013 og den efterfølgende debat om, hvorvidt anmeldelsen for racisme var på sin plads, er et eksempel på, hvordan Jehovas Vidner overskrider grænsen for, hvad man finder er acceptabelt i det danske samfund. Som nævnt i artiklens begyndelse bevirkede talen ved sommerstævnet, at Jehovas Vidner blev anmeldt efter straffelovens §266b, fordi den sammenlignede frafaldne Jehovas Vidner med en smittefarlig sygdom . I løbet af de næste uger affødte sagen 83 artikler i danske trykte medier. ${ }^{8}$ Det var karakteristisk, at det i høj grad var artikler fra de regionale og lokale aviser, som tog sagen op, samt at sagen i flere tilfælde endte på lederplads. ${ }^{9}$ Den store spredning i mediedækningen afspejler, at Jehovas Vidner, som nævnt ovenfor, er en af de største religiøse minoriteter i Danmark og er geografisk spredt over hele landet. Tilstrækkeligt mange danskere har kendskab til bevægelsen til, at historier om den kan synes relevante for lederskribenter, både lokalt og nationalt. I løbet af de uger, hvor debatten fandt sted, skete der også en udvikling af artiklernes karakter. I de første dage var det særligt selve nyheden, om at Jehovas Vidner blev anmeldt, som dominerede medierne. Derfor var det også især juridiske argumenter og juridiske eksperter, der blev hørt. F.eks. udtalte lederen af Dokumentations- og Rådgivningscentret mod Racediskrimination, Niels-Erik Hansen, at “Talerne er den samme slags retorik, som man hørte mod jøderne i Europa i 1930'erne. Det er præcis det, som racismeparagraffen er sat i verden for at dæmme op for" (Kristeligt Folkeblad 25. juli 2013). Vinklen i artiklerne var, at når sådanne udtalelser kom til udtryk i det offentlige rum, så faldt de ind under racismeparagraffen. Vinklen blev

8 Søgningen er foretaget gennem Infomedia i perioden 16. juli 2013 - 30. august 2013.

9 Dagbladet Struer 26. juli 2013. Politiken 27. juli 2013. Morsø Folkeblad 29. juli 2013 og Kristeligt Folkeblad 1. august 2013. 
fulgt op af andre artikler, som efterlyste øget kontrol med de danske trossamfund, og herunder muligheden for at fratage Jehovas Vidner deres godkendelse som trossamfund. Dette var blandt andet tilfældet da jurist og professor Lisbet Christoffersen udtalte: “Vi skal sætte nogle grænser inden for den plads, der skal være til religionsog ytringsfriheden, og jeg kan godt forstå de tidligere Jehovas Vidner, der siger, at nu er det nok, for det er meget grove ord, der bliver sagt om dem" (Politiken 29. juli 2013, 6). Efterhånden kom dog også andre aktører på banen, som, i lighed med repræsentanter fra bevægelsen selv, påpegede, at henvisningerne til sygdom kom fra Bibelen, og at et forbud dermed ville stå i vejen for religionsfriheden. F.eks. skrev sognepræst Katrine Lilleør, at “Det er kun totalitære stater, der forbyder tro. Det er Jehovas vidners demokratiske ret at tro, at deres frafaldne er giftig jord. De bør også have ret til at sige det højt. Så højt, at vi alle kan høre, hvad Jehovas Vidner er for nogle" (Berlingske Tidende 3. august 2013, 20). På samme linje skrev forhenværende kirkeminister Birthe Rønn Hornbech:

Jamen det er da for galt, at Jehovas Vidner forfølger tidligere medlemmer. Ja, det er det. Men det er der allerede lovgivet for. Efter straffeloven kan der gives tilhold, hvis medlemmer af trossamfundet chikanerer frafaldne og bliver ved med at trænge ind på dem

(Kristeligt Folkeblad 16. august 2014, 7).

Debatten viste, at der var røster i majoriteten, som ønskede at ekskludere Jehovas Vidner fra den danske religionsmodel, mens andre debattører påviste det juridisk og politiske uholdbare $\mathrm{i}$ at anfægte godkendelsen af Jehovas Vidner som trossamfund eller at foretage indskrænkninger i deres ytringsfrihed.

Debatten inddrog også et sociologisk perspektiv, som omhandlede Jehovas Vidners praksis med at afskære kontakten til tidligere medlemmer. Temaet var her de personlige omkostninger, som er forbundet med denne praksis. F.eks. blev det radikale folketingsmedlem Marlene Borst Hansen citeret for at sige: "Jeg tror, at vi alle sammen har hørt historier eller kender mennesker, for hvem det har været meget svært at bryde ud af Jehovas Vidner. Det er sørgeligt, og det er klart, at når det er et krav i loven, ${ }^{10}$ så skal vi sikre os, at de anerkendte trossamfund lever op til det" (Politiken 25. juli 2013). En lignende udtalelse kom fra Støttegruppen for tidligere Jehovas Vidners formand, Poul Dal. Han udtalte:

Og netop dette vilkår - at miste sin familie - har de fleste på træffet tilfælles. Som tidligere Jehovas Vidne har man et vist behov for at møde andre som en selv, et behov, som næsten kan sammenlignes med det behov, overlevende fra koncentrationslejre har for at møde andre, der har samme skæbne (Kristeligt Folkeblad 17. august 2013, 4).

Det bør bemærkes, at der i den danske lovgivning ikke findes en lov, hvor uhindret udmeldelse er et krav for et trossamfunds godkendelse. I Vejledende retningsliner udarbejdet af det Rådgivende Udvalg vedr. Trossamfund (2011, opdateret 27. marts 2014), skrives der ikke om praksis for fratagelse af en anbefaling til godkendelse. Klarere juridiske retningslinjer for trossamfund uden for folkekirkenvar et punkt, som professor Lisbet Christoffersen rejste i løbet af den ovennævnte mediedebat. Se fx Lisbet Christoffersen "Ingen holder øje med trossamfundene i Danmark", Politiken, 29. juli 2013. 
I forhold til citater som disse er det spørgsmålet om, hvad der er acceptabel religion, som er temaet. Det forhold, at Jehovas Vidner lader religiøse normer gå over familiesammenhold, vurderes, i ovenstående citater, negativt. Dette gælder også den tematik, som omhandler spørgsmålet om Jehovas Vidners "danskhed". Dette emne berørte chefredaktøren for Dagbladet Ringkøbing i følgende leder:

I bund og grund er al fundamentalisme usund. Om den udspringer fra den islamiske verden, fra politiske partier eller Jehovas Vidner er sådan set underordnet, for med fundamentalismen følger fanatismen, og i min verden er det svært at komme i tanke om noget mere ubehageligt - eller udansk for den sags skyld" (Dagbladet Ringkøbing 26. juli 2013, 13).

Lederskribenten i Morsø Folkeblad var enig:

Religion bør være et middel til at opnå et bedre liv for sig selv og sammen med andre. Manipulation og trusler hører ikke hjemme i den sammenhæng, og finder man belæg for den opførsel i Bibelen eller andre hellige skrifter, kan man kun sige: Vorherre bevares! (Morsø Folkeblad 29. juli 2013, 2).

I ovenstående indlæg er pointen, at religion er og bør være ikke-fundamentalistisk, og det som gør, at man får et godt liv sammen. Religiøse krav må således ikke sættes over frihed, over fællesskabet eller skabe ufred. I lederskribenternes udsagn understreger de Jehovas Vidners omstridte position i den danske religionsmodels grænseflade, idet at Jehovas Vidner lader religiøse bud påvirke deres handlinger på en måde, som har negativ effekt på det danske samfund.

Det er karakteristisk for alle artiklerne i (dags)pressen, at argumentationen er sekulær. Artiklernes forfattere argumenterer i forhold til dansk jura, i forhold til individets ve og vel og i forhold til danske normer. Der påkaldes ikke transcendente kræfter. Det synes selvfølgeligt i en dansk avis, men det indebærer, at Jehovas Vidner får mindre legitimitet. Ved ikke at anerkende religiøse argumenter bliver disse argumenter underordnet et krav om, at de skal indpasses i en sekulær kontekst. Bevægelser der, ligesom Jehovas Vidner, handler ud fra en religiøs legitimering, befinder sig i strid med de normer som udgør et sekulært samfund.

\section{I grænsefladen af den danske religionsmodel}

Jehovas Vidner er i grænsefladen af den danske religionsmodel. Jeg har dog også undersøgt nogle andre aspekter end de juridiske i diskussionen om Jehovas Vidner som et grænsetilfælde. Historisk set, og sammenlignet med den danske folkekirke, er bevægelsen ny, men den har i løbet af de sidste hundrede år bevæget sig i retning af at blive accepteret som en del af det danske religiøse landskab. Det ses gennem bevægelsens forholdsvis store udbredelse her i landet og især gennem den accept af bevægelsens særstandpunkter, som giver sig til udtryk i den danske lovgivning. 
Teologisk set er bevægelsen principielt stadig langt fra luthersk kristendom. Jehovas Vidners afvisning af treenighedslæren, deres eskatologi og andre religiøse minoritets- særstandpunkter indebærer, at de er på kant med de store kirkesamfund. I en dansk sammenhæng bør det dog bemærkes, at de teologiske uenigheder fylder mindre i dag end i bevægelsens tidlige historie. Den afteologisering, som er foregået i Danmark, indebærer, at den teologiske lære, som folkekirken bekender sig til, står uklar for mange danskere (Andersen \& Lüchau 2011, 81). Dermed ikke sagt, at Jehovas Vidner er accepteret teologisk i Danmark i dag, blot at kontroverserne er blevet mindre. Sociologisk set er Jehovas Vidner en del af det danske samfund og lever og arbejder sammen med majoriteten. Bevægelsens normer er dog på kanten af de majoritetsdanske. Dette er mest udtalt i forhold til spørgsmålet om udelukkelse af medlemmer, som bryder med Jehovas Vidners religiøse normer. Dette sidste hænger sammen med det overordnede kontrovers: at Jehovas Vidner lader deres religiøse normer være bestemmende for deres retorik og omgang med majoritetssamfundet. Som eksemplet med artiklerne i forbindelse med racisme-anklagen viser, accepteres en religiøs diskurs ikke. Som nævnt i begyndelsen af artiklen, er det danske samfund kendetegnet ved sekularisme, liberalisme og et udpræget frihedsbegreb. I forhold til disse punkter står Jehovas Vidner udenfor. Samtidig viser Jehovas Vidners udvikling gennem det sidste århundrede, at grænserne rykkes. Selv om Jehovas Vidner stadig er matter out of place i forhold til det danske samfund og den danske religionsmodel, bevæger de sig gradvist i retning af en inklusion.

\section{LITTERATUR}

Andersen, Peter B. \& Peter Lüchau

2011 "Individualisering og aftraditionalisering af danskernes religiøse værdier", in: Peter Gundelach, ed, Små og store forandringer. Danskernes værdier siden 1981. Hans Reitzels forlag, København, 76-96.

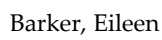

2006 "We've Got to Draw the Line Somewhere: An Exploration of Boundaries that Define Locations of Religious Identity", Social Compass 53 (2), 201-213.

1994 "But is it a Genuine Religion?", in: A. Greil \& T. Robbins, eds., Between Sacred and Secular: Research and Theory on Quasi-religion. Religion and the Social Order 4, JAI Press, Inc., Greenwich \& London.

Beckford, James A.

1975 The Trumphet of Prophecy. A Sociological Study of Jehovah's Witnesses, Basil Blackwell, Oxford.

Bruun, Christoffer Emil

2013 "Retten til sludder: Frihed for Jehova såvel som for Thor", Politiken 27. juli, 1.

Christensen, Søren

2013 "Her hjælper politiet ikke", Dagbladet Struer, 26. juli, 1.

Christoffersen, Lisbet

2013 "Ingen holder øje med trossamfundene i Danmark", Politiken, 29. juli 2013.

Christoffersen, Lisbet, Hans Raun Iversen, Niels Kærgård og Margit Warburg

2012 "Den danske religionsmodel", in: Lisbet Christoffersen at al., eds., Fremtidens danske Religionsmodel, Anis, København, 23-39.

2012 "Den danske religionsmodel på vej mod et tippepunkt", in: Lisbet Christoffersen et al., eds., 
Fremtidens danske Religionsmodel, Anis, København, 381-84.

Chryssides, George D.

2008 Historical Dictionary of Jehovah's Witnesses, The Scarecrow Press, Lanham, Maryham.

Hornbech, Birthe Rønn

2013 "Overvågningssamfundet: Der bør siges fra over for kontrol af vor religionsudøvelse", Kristeligt Folkeblad, 16. august, 6.

Hvithamar, Annika

2007 Verdensreligioner i Danmark - Kristendom, Gyldendal, København.

Iversen, Hans Raun

2012 "Den danske folkekirke i nordisk belysning", in: Lisbet Christoffersen et al., eds., Fremtidens danske Religionsmodel, Anis, København, 23-39.

Jensen, Jørgen Skafte

1991 "Jehovas Vidner", in: Tim Jensen, ed, Minoritetsreligioner i Danmark - Religionssociologisk set, Columbus, Viborg, 151-177.

Jørgensen, Jonas Adelin

2012 "Sindbilledsprog og hjertefrihed", in: Lisbet Christoffersen et al., eds., Fremtidens danske Religionsmodel, Anis, København, 183-197.

Korsgaard, Kristine

2013 "Ingen holder øje med trossamfundene i Danmark", Politiken, 29. juli, 6.

Krag, Helen

2007 Mangfoldighed, magt og minoriteter - introduktion til minoritetsforskningens teorier, Forlaget Samfundslitteratur, Frederiksberg.

Lilleør, Katrine

2013 "Jehovas grovheder", Berlingske Tidende, 3. august, 20.

Madsen, Anders Ellebæk

2013 "Gør ikke Bibelen kriminel", Kristeligt Folkeblad, 1. august, 2.

Militærnægterloven

2001 https://www.retsinformation.dk/forms/R0710.aspx?id=6464 (set 30.6.2014).

Neiiendam, Michael

1948 Frikirker og Sekter, Gad, København.

Politianmelselse

“Politianmeldelse af Vagttårnets Bibel- og Traktatselskab, danske afdeling, Stenhusvej 28, 4300 Holbæk, 30 juli").

Schnabel, Laura Elisabeth

2013 "Tidligere Jehovas Vidner holder møde", Kristeligt Folkeblad, 17. august, 4.

Schnabel, Laura Elisabeth og Nikolaj Krak

2013 "Jehovas Vidner risikerer racismesag", Kristeligt Folkeblad, 25. juli, 1.

Straffeloven

2013 https://www.retsinformation.dk/Forms/r0710.aspx?id=152827 (set 30.6.2014).

Støttegruppen for tidligere Jehovas Vidner

2013 "Politianmeldelse af Vagttårnets Bibel- og Traktatselskab, danske afdeling, Stenhusvej 28, 4300 Holbæk, 30 juli." http://www.kristeligt-dagblad.dk/modules/fsArticle/download.php?fileid=251 (set 23.3.2014).

Sundhedsloven

2010 https://www.retsinformation.dk/forms/R0710.aspx?id=130455 (set 30.6.2014).

Svarrer, Jens Peter

2013 "Religions(u)frihed", Morsø Folkeblad, 29. juli, 1. 
Støttegruppen for tidligere Jehovas Vidner

2013 "Politianmeldelse af Vagttårnets Bibel- og Traktatselskab. Program", danske afdeling, Stenhusvej 28, 4300 Holbæk, 30. juli.

Warburg, Margit

1996 “Lige ret for Loke såvel som for Thor? Religionsbegreber og retspraksis i forbindelse med religioner uden for folkekirken", Chaos. Dansk-norsk tidsskrift for religionshistoriske studier 26, 9-32.

Watch Tower Bible and Tract Society of Pennsylvania

2014 Jehovas Vidners årbog 2014. Wachtturm Bibel- und Traktatgesellschaft der Zeugen Jehovas, E. V. Selters/Taunus.

2013 "Hvad siger Bibelen? Sex før ægteskabet”, Vågn op! 9, 4-5.

2012 “Unge spørger: Hvordan kan jeg forklare Bibelens syn på homoseksualitet?", Vågn op! 1, 28-29.

2010 "Hvad siger Bibelen?: Hvordan skal man se på det at bede til 'helgener'?", Vågn op! 11, $20-21$

2009 "Hvad siger Bibelen?: Bør der være et skel mellem præster og lægfolk?”, Vågn op! 8, 22-23.

2008 "Hvad siger Bibelen? Skal Gud tilbedes ved hjælp af billeder? Vån op! 8, 20-21.

2005 Hvad er det Bibelen virkelig lærer? Watch Tower Bible and Tract Society of New York.

2004 "Skal præster blande sig i politik?", Vågn op! 5, 3-5.

1996 “Det, der tilkommer kejseren", Vagttårnet 5, 20-21.

1993 Jehovas Vidner. Forkyndere af Guds rige. Watch Tower Bible and Tract Society of New York.

[N.a.]

2013 Jehovas Vidners områdestæone, Program, [N.p].

[N.a.]

2013 "Tag dig i agt for frafaldne", Transskription af lydfil foretaget af David Bille Maagaard, http://www.x-jv.dk/nyt/transcript_frafaldne.html, (set 30.6.2014).

Annika Hvithamar, lektor, ph.d. Institut for Tværkulturelle og Regionale Studier, Københavns Universitet 
